\title{
Creative Inquiry in Applied Linguistics: Language, Communication and the Arts
}

\author{
Jessica Bradley, University of Sheffield \\ Lou Harvey, University of Leeds
}

\begin{abstract}
Introduction
In this chapter we consider what creative inquiry in applied linguistics is, how creative inquiry has been used in applied linguistics research and how it might extend our understandings of communication and language in relation to 'realworld problems' (Brumfit 1995: 27). We present a diverse body of applied linguistics research from a range of contexts which works with, into and through the arts in multiple ways. By considering these projects, broad-ranging in scope, in place and in questions, and grounded in different forms of arts practice, we ask what the relationship is between communication and creative arts and, importantly, what the affordances of this relationship might be for the field of applied linguistics. This chapter therefore offers an introductory discussion of work engaging with creative inquiry and sets out some theoretical considerations for this emerging body of research and practice.
\end{abstract}

\section{How to cite this book chapter:}

Bradley, J. and Harvey, L. 2019. Creative Inquiry in Applied Linguistics: Language, Communication and the Arts. In: Wright, C., Harvey, L. and Simpson, J. (eds.) Voices and Practices in Applied Linguistics: Diversifying a Discipline, pp. 91-107. York: White Rose University Press. DOI: https://doi.org/10.22599/BAAL1.f. Licence: CC BY-NC 4.0 


\section{What is creative inquiry?}

As we will exemplify, the arts, broadly configured, have become an increasing focus of attention for applied linguists, with a rich diversity of approaches and models of working. We have found it useful thus far to describe this work following Patricia Leavy's definition of creative inquiry, as 'any social research or human inquiry that adapts the tenets of the creative arts as a part of the methodology' (Jones \& Leavy 2014: 1). While we take Leavy's use of methodology here in its broadest sense, there is a risk that creative inquiry is seen as focusing solely on method and that its theoretical affordances and implications remain unmined. However, recent work on three large UK-based research projects (2014-2018), funded under the Arts and Humanities Research Council's 'Translating Cultures' theme, has done much to both exemplify the affordances of creative inquiry in applied linguistics and to establish and develop it theoretically as well as methodologically.

The first, 'Researching Multilingually at the Borders of Language, the Body, Law and the State' (led by Alison Phipps, University of Glasgow) engaged an international and interdisciplinary team of researchers to study translation and interpretation at different borders, where people and their languages must often function (or indeed not function) within contexts of extreme pain and pressure. The project integrated creative practitioners and their practice into the project design in order to (a) translate data, concepts and findings into live performance and (b) create and deliver drama workshops to 'allow for the exposure of otherwise silent dynamics of language, power, narrative and pain relevant to participants in each context' (RM@Borders project website). The project therefore blurred the boundaries between what is traditionally considered academic and what is considered art, and between linguistic, non-linguistic and expressive or 'artistic' forms of communication.

The second of these projects, 'Translation and Translanguaging: Investigating Linguistic and Cultural Transformations in Superdiverse Wards in Four UK Cities' (TLANG) project (led by Angela Creese, formerly University of Birmingham, now University of Stirling), explored concepts of dynamic multilingualism in superdiverse urban settings. Grounded in linguistic ethnography, the research carried out across four cities (Birmingham, Cardiff, Leeds and London) developed a strong shift towards the visual and the embodied (Blackledge \& Creese 2017; Zhu, Wei \& Lyons 2017). This built on ongoing theoretical notions of translanguaging, as a concept describing dynamic multilingual and multimodal practice in everyday contexts. TLANG incorporated creative practice in multiple ways. The research extended to include a Leverhulme Artist in Residence project for co-investigator Zhu Hua (Birkbeck College, University of London) with visual artist and choreographer Ella McCartney. Creative practitioners, including choreographer and dancer Rosie Kay (Rosie Kay Dance), Mohammed Ali (Soul City Arts) and composer Jonathan Dove collaborated 
with project researchers in a series of Creative Arts Labs through which they engaged with multilingual project data (the Creative Arts Labs process is captured as a project film www.tlang.org.uk). Additional arts-informed projects stemmed from TLANG research, including visual arts in contexts of migration and language learning in multilingual contexts (McKay \& Bradley 2016) and poetry (Blackledge 2019). The third large project, 'Transnationalizing Modern Languages: Mobility, Identity and Translation in Modern Italian Cultures' (TML, led by Charles Burdett, University of Durham), examined forms of mobility and Italian diaspora, linking closely to the role of the arts in circulation of cultural objects. Project outputs included textual and visual material and an exhibition, 'Beyond Borders: Transnational Italy', in London and Rome. The artist products here focused on mobility and cultural transformation and were integral to the research design.

Creative strands are also embedded across the AHRC's four Open World Research Initiative programmes (2016-2020), which seek to develop transdisciplinary approaches to modern languages and the role languages play in addressing key challenges in society. In particular, the 'Creative Multilingualism' programme (led by Katrin Kohl, University of Oxford) focuses on the interplay of language and creativity and encompasses multilingual theatre pedagogy.

We include these examples because we see them as reflecting a growing recognition of the potential for these kinds of hybrid research projects, which have traditionally had more visibility across the humanities and the arts than in the (arguably more social science-oriented) field of applied linguistics. We will now look more closely at how specific research projects in applied linguistics have used creative inquiry in different ways.

\section{How has creative inquiry been used in applied linguistics research?}

Here we turn to what we see as three broad categories of work engaging with creative inquiry:

- research with the arts (i.e., what can working with the arts tell us about applied linguistics?);

- research into the arts (i.e., what can working with applied linguistics tell us about the arts?); and

- research through the arts (i.e., using arts-based and arts-informed methods as theory and methodology).

These categories have been useful for us in making sense of the work taking place under the aegis of creative inquiry, and insofar as this chapter presents a fairly new theoretical and methodological paradigm they are intended to be 
useful in helping the reader to make sense likewise and to offer a productive heuristic for beginning to map out this area and its futures in a coherent way. However, we are aware of the ontological implications of drawing boundaries (Hekman 2010) and of the reductionist potential of imposing such artificial structures (Latour 1991). We will therefore highlight throughout our discussion how these categories inter-relate and how the examples within them often move across and beyond the boundaries we have created.

\section{Research with the arts}

The first category focuses on the exploration of arts as the objects of communication research, for example as multimodal artefacts and means of communication in specific social and political contexts (Bradley \& Moore 2018; Lee 2015; Crowley 2017). Broadly, work categorised as with the arts investigates how artistic artefacts - of which language may or may not be a part - can shed light on practices and understandings of communication (see recent research which extends the scope of linguistic landscapes, for example Pennycook 2017).

Tony Crowley's paper 'Language, History and Creativity', presented at the BAAL 2017 Creative Inquiry Invited Colloquium, offered a visual essay on what he describes as a 'life-time's engagement with Ireland, particularly the cultural and political issues involved in the conflict in Northern Ireland' (Crowley 2017). Crowley's research in this area stemmed from a period working as a children's playscheme volunteer in Divis Flats and the Lower Falls in West Belfast as a student in 1979. During this time, he became interested in the ways in which language was used in social and political graffiti in Republican and Loyalist areas and began to photograph it. As he documented the murals, he started to see that these signs had multiple functions, including creating a sense of both belonging and exclusion. Crowley continued to develop his research into these landscapes, and his photographs now form a historical archive of over 22,000 works spanning nearly 40 years. His starting point is the everyday, moving beyond analysis of what people were saying towards what he describes as 'the where of language' (Crowley 2017, emphasis added). He found that these images, viewed collectively, perform the complex motivations for these utterances and their emplacement in (contested) public spaces in a way which extends beyond words alone.

Crowley considers his research here as a 'creative form of inquiry into language' (2017). This creativity lies not only in the methods he uses (photography and digital archiving) but also in his epistemological approach to his work. His research focuses on the arts as objects of analysis but starts from an affective, experiential curiosity (see Sagan 2017) from which questions and concepts emerged rather than being articulated a priori (see Phipps 2013) and which is grounded in a desire to open up rather than pin down knowledge (Turvey \& Walton 2017). 
Translation studies scholar Tong King Lee (2015) considers two art works by contemporary Chinese artist Xu Bing through the lens of translanguaging. Here translanguaging itself is seen as a catalyst or 'resource' for creativity in communicative practice (2015: 441) and, although the concept is usually applied to interaction and spoken language, focusing on the visual and the inclusion of text offers a perspective on the role of art in 'articulating a politics of (mis)recognition, (un)readability and (in)communicability' (ibid.). In text - and therefore in art, as in the cases Lee discusses - translanguaging and other features of dynamic multilingualism are enacted deliberately: 'such premeditation and non-spontaneity afford codeswitching and translanguaging practices a higher degree of deliberation and greater space for rhetorical manoeuvre' (2015: 442). Lee brings translanguaging into interaction with the 'translational,' which he considers a site of semiotic 'hybridity' (2015: 443). This site allows for and enables a movement across semiotic modes. The artworks exemplify this mobility and dynamism and shed light on the multimodal affordances of translanguaging as a concept. As Lee states, 'this view is especially pertinent to visual art, where non-verbal signification is central' (2015: 444).

Lee concludes that, in the artworks he examines, translanguaging has multiple functions. Continuity between orthographic systems (and therefore between 'two systems of cultural representation' (2015: 462)) is both built up and broken down. He sees translanguaging spaces as Homi Bhabha's 'third narrative' (1994), crossing borders, including disciplinary ones. Here Lee demonstrates the importance of attending to artworks and how linguistic concepts can be further interrogated in this way.

Multilingualism in artistic works was the subject of a special issue of the Journal of Bilingualism published in 2014, edited by Penelope Gardner-Chloros, which featured a range of contexts, from literature to theatre. Gardner-Chloros suggests that the arts, again broadly configured, are sites of rich multilingualism yet relatively unexplored from a linguistic perspective. Adam Jaworski's article in this issue (2014) focuses on another concept used in discussions of dynamic multilingualism, 'metrolingualism' (Otsuji \& Pennycook 2010; Pennycook \& Otsuji 2015). He considers that the creative use of multiple languages as applied to visual art enables a multimodal perspective on 'metrolingualism.' Theoretically, Jaworski states that this 'suggests a reframing of metrolingualism as heteroglossia' (2014: 134). For him, examining artworks in this way not only develops understandings of dynamic multilingual (in this case metrolingual) practice, but also supports a multimodal turn:

The examples of art examined above certainly appear to support a more up-to-date metrolingual (and/or polylingual) view of language, but it may be useful to extend the range of semiotic features amenable to metrolingual usage to include a whole gamut of multimodal resources that work alongside the strictly linguistic ones.

(Jaworski 2014: 151) 


\section{Conclusion: De-centring language}

Work categorised as with the arts is therefore engaged with consideration of the relationship of language to other modes of communication, to humans, nonhumans, objects and places (see also Pennycook 2018; Frimberger, White \& Ma 2017) and to affect, materiality and embodiment (Appleby \& Pennycook 2017; Frimberger 2017). This rethinking of the relationships between language, affect and materiality has entailed a challenge to the primacy of logocentric representationalism, in which language is the privileged vehicle for knowing the world (MacLure 2013; Thurlow 2016). Meeting this challenge requires a decentring or 'provincializing' of language, recognising its limits and acknowledging 'a world of communicating and knowing beyond - or beside/s - words' (Thurlow 2016: 503):

Language is deposed from its god-like centrality in the construction and regulation of worldly affairs, to become one element in a manifold of forces and intensities that are moving, connecting and diverging.

(MacLure 2013: 660)

\section{Research into the arts}

This second perspective relates to the application of more traditional applied linguistics methods for researching creative and artistic practices, contexts and collaborations (e.g., Bradley 2018; Bradley \& Moore 2018; Hazel, 2017; Moore et al. 2020). Research into the arts might consider arts educational and training contexts and the role of language within these. This reflects an approach more aligned with established research practice in applied linguistics, with creative practice as a site in which the 'real-life problems for which language is a central issue' (Brumfit 1995: 27) are tangible. Arts spaces are also spaces of learning there is much that can be taken from applied linguistics into creative practice, and communication and language are arguably concerns for creative practitioners across artistic fields.

Spencer Hazel carried out research with Danish theatre ensembles, conceptualising this kind of collaborative yet short-term endeavour as 'transient multilingual project communities' and focusing on language and communicative practices within these project spaces (2017). The methodology he followed embedded him as 'researcher-in-residence' (p. 311), and he was interested not just in the ways in which the practitioners used language but also in processes of collaboration (2017: 310). Hazel employed methods drawing from ethnomethodology-inspired interactional analysis and what he describes as an 'emic praxeological perspective' (2017: 311) as researcher emplaced within the production spaces he was researching. His rationale for researching theatre practice relates in part to the transience of production processes and the 
creative products - the theatre productions. He links this to the transient nature of community and how it only comes into being through its enactment (2017: 321 ). In addition to considering communities and social practices around creative processes, Hazel's findings also relate to multilingual practices in this context - a 'gradual shift away from "language standardization" - and how it is shaped by the creative production:

Moreover, the language(s) chosen for carrying out particular activities between members of the team evidenced a shift over time, and the language used between configurations of members also appeared to become less constrained, rather than shifting toward one designated set of linguistic resources being adopted as an official medium of interaction. Rather than multilingual usage being treated as problematic, we saw evidence of participants' orientation to exploring the communicative possibilities of the entire available range of languages and language competences.

(Hazel 2017: 322)

In this case, investigating creative practice shed light on the creative use of language made possible through these ways of working (see also Zezulka, this volume). The potential application of these findings transcends disciplines. For example, they might inform arts education policy around access to creative subjects in schools and colleges. Likewise, there is a role for these observations of interactions in transient creative spaces in language education policy, for example in the UK educational context.

The study of communication in creative contexts can help us to articulate what it is that creative modes do, how they work and specifically how they work for the people and organisations engaging in them. Andrea Milde's research applies analytical frameworks from linguistics to the creative industries. She identifies a substantial research gap here, pointing out that 'everyday communication in arts practice is just as important and relevant to society as communication in other areas of life' (2nd BAAL Colloquium on Creative Inquiry, York St John, 2018). This gap has social implications as the arts - somewhat controversially - increasingly step in where government services are retreating, in healthcare, wellbeing, education and migrant and social support; work such as Milde's demonstrates the potential for the analysis of communication in creative contexts to contribute to the issue of evaluation of learning, engagement and impact which is a pressing concern for artists (see Rowe \& Reason 2017).

In a paper presented at the Creative Inquiry colloquium, co-written with Jussi Lehtonen, Eeva-Leena Happakangas and Harith Raad Salih, Sari Pöyhönen described 'Toinen Koti', or 'Other Home', a project conducted in collaboration with the Helsinki-based Finnish National Theatre. This joint inquiry asked what integration is, how it is understood and what its relationship is with the concept of home, using linguistic ethnography and applied theatre practice. This project took place at the nexus of applied theatre and applied linguistics, 
with Pöyhönen embedded within the project design as 'in-house linguistic ethnographer' for the production and performance of the theatre piece, which was devised and performed by people from refugee backgrounds, all of whom had been actively involved in the arts previously. The project built on and linked to Pöyhönen's research into migration and language in Finland, enhancing understandings of what it means to be mobile and to build a new life as a refugee in increasingly hostile times. Communication - and miscommunication - were central themes for the piece. The play asked, "how can we learn to know others if we do not understand, and do not want to understand, what they say' (Simpson 2018). Pöyhönen explains the necessity for this kind of interdisciplinary hybrid research and practice for her as a 'linguistic ethnographer':

I do research to do with language, so my first point is to look at linguistic resources which people have to hand to negotiate with. But I wanted to go beyond language, to understand not just the linguistic ways of making meaning but the whole semiosis. And in doing so, I realised how restricted I am with my concern with language, how much I miss when I don't look at other people's resources.

(Interview with James Simpson, 2018)

Toinen Koti exemplifies the inherent inter - or trans - disciplinarity of work in this area, and the creative affordances this offers. Analytically, as with work by Lee and Jaworski described above, there are clear implications for extending the analytical lens beyond language and for innovative methods (see also Bradley \& Moore 2018).

\section{Conclusion: Trans-methodologies}

Research into the arts allows for the tracing of voices through creative processes (e.g., Harvey 2020). It also sheds light on how artefacts are made collaboratively, helping to understand (co-/trans-) authorship and audience responses. Moreover, these hybrid practices work to broaden the analysis beyond language, into semiotics and into voice, and may shed a wider pool of light onto how knowledge is created and how collaboration, making and learning take place across, through and beyond various boundaries (following Jones 2016). There are therefore particular implications for understanding knowledge creation in creative and collaborative practice that go beyond what might be first anticipated at research proposal stage.

\section{Research through the arts}

This final category - research through the arts - considers the use of creative inquiry for understanding and researching communication. Here it aligns with 
what Lynne Butler-Kisber describes as arts-informed inquiry, which adopts different forms of 'art' in order to both 'interpret and portray' (2010: 8). Artsinformed inquiry is differentiated from arts-based inquiry in that the resultant product might not be an artefact. In this sense it is a fluid and emergent way of working, one which aligns with bricolage (see Bradley \& Atkinson 2020). Artsinformed methods might include drawing, painting and photography.

Gail Prasad (2018) describes the use of collage in investigating children's understandings of being plurilingual. She was motivated to establish a way of working which included children aged between 9 and 11 as co-investigators. Collage as a democratic method emerged as a productive tool for enabling both reflection on being plurilingual and communication of these reflections (2017: 6-7). Its affordances were to enhance the children's engagement with the research and her own development as a researcher. Prasad herself trained in the method for two years before undertaking her research, in this way addressing one of the ethical challenges around the role of artistic expertise which is posed by these hybrid ways of working. She states:

Personally, as a researcher-artist, when I relax into the creative process of gathering, layering, (re)combining and juxtaposing images, I am able to make new connections and allow ideas to surface that are substantially different than when I try to make sense cognitively of multiple pieces of information in the classroom or at my desk in the office.

(Prasad 2018: 7)

For Prasad, creativity and plurilingualism are intrinsically linked and she views an alignment across them: 'Collage and plurilingualism as forms of creative self-expression offer a space for risk-taking, experimentation and the growth of new ideas and perspectives' (ibid.). As method they develop participation, flatten hierarchies and act as a tool for researcher reflection.

Likewise, and also using collage among a range of arts-informed methods, a transdisciplinary project developed by Jessica Bradley with artist-researcher Louise Atkinson (Bradley et al. 2018; Bradley \& Atkinson 2020) sought to build on wide-ranging and innovative research in linguistic landscapes (e.g., Barni \& Bagna 2015; Blommaert 2013). In collaboration with young people and educational centres in Leeds in the north of England, Bradley and Atkinson explored how Atkinson's practice as an artist-researcher could be used as tools for young people to respond to the linguistic landscapes of their schools and communities. Workshops were delivered which enabled participants to gain an insight into methods associated with ethnographic research, including observation and interviews. The young people then carried out their own fieldwork, collecting a series of multimodal data which focused on the linguistic landscapes of the streets around the educational centres. Acknowledging that the linguistic landscape is visual and embodied, the arts-informed methods enabled the project participants to consider the role of language and multilingualism in their daily lives. Creative outputs were considered more than simply dissemination 
of the young people's work, functioning additionally as the synthesis of findings and generation of ideas. The project is continuing, funded by the AHRC OWRI programme 'Cross Language Dynamics' in collaboration with Multilingual Manchester, and encompasses a series of nexus points around modern languages and applied linguistics, visual arts and photography and research and engagement.

Lou Harvey, with Brad McCormick and Katy Vanden from theatre company Cap-a-Pie (2020), used Cap-a-Pie's Dramatic Enquiry technique to gain insights into, and also enhance, the intercultural learning of UK university students. They developed a fictional scenario which raised themes and questions around communication and mis/understanding, which participants explored through a series of facilitated creative activities: they were assigned fictional identities, which they inhabited throughout the enquiry, and then engaged in creative activities, such as making body sculptures and tableaux (where participants have to physically and silently manipulate the body of another to perform a concept, e.g., communication), writing poems and generating philosophical questions. The Dramatic Enquiry stood in contrast to much intercultural research in Higher Education, which often uses students' stories as a representation of their identities; instead, the fictional story was used as a basis for performing identities so that the participants' knowing was bound up with their being, with their embodied performance of something, and their learning took place through this entanglement. To quote the feminist new materialist philosopher Karen Barad: 'We don't obtain knowledge by standing outside the world; we know because we are of the world' (Barad 2007: 185). Epistemology and ontology are not separate but bound up together.

Harvey, McCormick and Vanden also undertook a project to develop Harvey's applied linguistics research for performance, in which they aimed to communicate to a public audience how it feels to not understand what is going on around you, especially in a context where you expect to understand (see Harvey et al. 2020). Through a performance with two actors, they deliberately put the audience in a position where they did not understand what was happening, by confusing them or by asking them to participate in particular ways. This evoked in the audience a strong affective response of discomfort and uncertainty, a response which they theorised as stemming from a shared human desire to make meaning, to communicate and understand and be understood (ibid.). The audience shared the affective, embodied discomfort of misunderstanding and being misunderstood, in a place where they expected to understand, a process which Harvey theorised as a pedagogy of solidarity (ibid.). Again, their knowing was bound up with their embodied experience, their being. And this is where the learning took place: it led the audience to reflect on their own behaviour, their effect on others and their own responsibilities in communication.

Zhuomin Huang's doctoral research used a variety of creative visual artsbased methods to ask questions about intercultural personhood in Manchester, 
UK. Huang's focus is on methodology and how creative inquiry develops different understandings of intercultural personhood than methods more traditionally associated with educational research. Using multiple arts-informed methods including 'free style painting' and 'art-gallery walking', she developed a methodology for her research entitled 'Multislicing Semiotic Analysis', which she describes as a 'systematic approach for directly engaging with the meanings of her visual and verbal dataset' (Huang 2018). Huang's work is underpinned by Alfonso Montuori's conceptualisation of creative inquiry as 'self-reflection' on the knowledge-making process (e.g., Montuori 2011).

\section{Conclusion: Application of arts-informed approaches}

For the projects described above, creative inquiry here can be seen in one sense as dissemination and as communication with participants across different stages of research. But it also becomes something entirely new through collaboration and openness to bringing in new ways of approaching research. Within the broader heading of creative inquiry, arts-informed approaches are particularly used for investigating learning, community and belonging (see also Bradley et al. 2018; Harvey \& Vanden 2017; Huang 2017; McKay \& Bradley 2016; Pöyhönen et al. 2017). Research through the arts is transdisciplinary and aligns with practice-as-research methods, drawing from across disciplines.

\section{Conclusion}

In writing this chapter we have sought to address the question of how creative inquiry can extend our understandings of communication and language in relation to 'real-world' problems. We have set out some initial thoughts on creative inquiry in applied linguistics - what it is and what it might be. But we are conscious that applied linguistics is a broad and inherently disciplinary field and any number of approaches might be considered creative in ethos, simply by a slight shift away from established methods. Therefore, to define creative inquiry under an applied linguistics 'umbrella' is a complex task and one undertaken with a certain degree of trepidation.

Here we have used examples from a range of contexts, including papers presented at the colloquium on Creative Inquiry at the 2017 BAAL Annual Meeting (Crowley 2017; Harvey and Vanden 2017; Huang 2017; Pöyhönen et al. 2017), which all linked, in focus and in scope, to the annual meeting's main theme of diversity: diversity in and diversity of applied linguistics. We posit that extending our theoretical and methodological lenses towards the arts has the potential to diversify our field in numerous ways. Moreover, as a dialogue between fields, between researchers and practitioners, working in this way can extend our lenses beyond those traditionally associated with applied linguistics. 
Here we consider this as bridging theory and methodology, going on to set out how creative inquiry serves to complexify knowledge and challenge borders.

\section{Complexifying knowledge, challenging borders}

The concept of 'disciplinarity', as discussed by Henry Widdowson in his chapter in this volume, is central to our discussion. As applied linguists we seek to understand how language works and issues relating to language use and language learning. Arguably, applied linguistics is not bound firmly to a discipline, following Halliday's definition of 'transdisciplinarity':

I say 'transdisciplinary' rather than 'inter-' or 'multidisciplinary' because the latter terms seem to me to imply that one still retains the disciplines as the locus of intellectual activity, while building bridges between them, or assembling them into a collection; whereas the real alternative is to supercede them, creating new forms of activity which are thematic rather than disciplinary in their orientation.

(Halliday 2001: 176, in Hult, 2010: 13)

We demonstrate that the projects described above resonate in some way with notions of crossing, subverting and complexifying traditionally-understood boundaries - between languages, nations, identity groups, disciplines, practices. Such boundary-crossing is also evident in current reflections on the nature and role of language itself: the influences of posthumanist thought (Braidotti 2013) and post-qualitative research approaches (Lather \& St Pierre 2013) are leading to a reconsideration of the relationship of language to humans, nonhumans, objects and places (Pennycook 2018; Frimberger, White \& Ma 2017) and to affect, materiality and embodiment (Appleby \& Pennycook 2017; Frimberger 2017). This rethinking of the relationship between language, affect and materiality entails a move away from logocentric representationalism, as argued above, and towards a performative orientation to knowledge, where methodology and theory, epistemology and ontology are entangled (Toohey 2018), and how we know is fundamental to what we know (Bayley 2016: 44). A performative orientation to knowledge requires a decentring of the privileged position of language, or what Thurlow (2016) calls 'provincializing' language, to reposition it in relation to other agents and materialities. We therefore consider the potential of creative inquiry to enable such a decentring of language (Harvey \& Vanden 2017; Harvey \& Bradley 2017), opening up different ways of knowing which do not privilege what is (verbally) expressed (Thurlow 2016) and enabling the articulation of what was previously unarticulated, unknown, unheard and undervalued. This has implications not only for the methods we employ to construct new knowledge but also for our understanding of communication and education and our work as applied linguists: our work does not take place 
in what Bayley calls a 'rehearsal space that remains locked behind the doors of an ivory tower' (2016: 44), but what we do makes the world. These examples therefore not only showcase the diversity of work in applied linguistics, but also contribute to the diversification of applied linguistics by offering possibilities for diversifying our understandings of language itself.

\section{Towards a creative turn in applied linguistics?}

In addition to the research described in this chapter, attention to the arts and creativity currently manifests itself in diverse ways and across multiple areas in applied linguistics - there is much work that we have been unable to cite within the scope of this short piece. A plethora of activity and potential for activity has emerged, seemingly connected in what we might consider a creative turn in applied linguistics. But this wide-ranging and sometimes peripheral activity also risks appearing incoherent for anyone who might peer in from outside. It also potentially unsettles our understandings of 'research.' The projects we have described here showcase multiple ways in which applied linguistics might engage with creative practitioners and vice versa. Although we understand it as 'research,' some of this work was enabled through projects institutionally conceptualised as impact (see Lawson \& Sayers 2016) and engagement (Facer \& Pahl 2017). Crucially, such work has created a space for this kind of hybrid activity, building on the developing body of research in this area, and commitment to finding ways for this kind of border-crossing work is necessary for transdisciplinary inquiry to emerge. But labelling collaborative inquiry with creative practitioners as impact, although often unlocking useful funding streams, potentially limits its affordances and marginalises it as peripheral, even instrumental. Moreover, in some cases, funding ringfenced for impact and engagement is not available for empirical inquiry, meaning that a project which starts as impact and develops into collaborative research might not be considered 'research', therefore restricting its application and dissemination.

A significant question for applied linguists developing research in this area and for us, as chapter authors and co-conveners of an AILA Research Network in Creative Inquiry and Applied Linguistics, is therefore how these threads might be woven together and how a body of work, diverse in output and broad in scope, might be underpinned by a shared ethos. What might that shared ethos be? How do we communicate what we are doing? And, crucially, how might research and practice in this area be relevant for our peers? This is a conversation we intend to continue, but for now we offer our own conclusion that the relevance of creative inquiry is in its fundamental generativity. It offers an approach to research and education which can encompass people's complex communicative, affective, experiential and political realities. In its challenge of accepted boundaries it opens up without also closing down - it enables and/ and instead of either/or. It disrupts any kind of fixed or binary orientation and 
enables us not only to imagine, but also to collectively make, 'a world distinct from what we already are' (Weinstein \& Colebrook 2017: 4; Toohey 2018). It can lead to greater opportunities for people who have different access to dominant languages, or indeed any language; for understanding people's affective and embodied ways of understanding and knowing and for understanding how communication is and can be used creatively for learning and for justice.

\section{References}

Appleby, R. and Pennycook, A. 2017 Swimming with sharks, ecological feminism and posthuman language politics. Critical Inquiry in Language Studies, 14(2-3): 239-261.

Barad, K. 2007 Meeting the universe halfway: Quantum physics and the entanglement of matter and meaning. Durham, NC: Duke University Press.

Barni, M. and Bagna, C. 2015 The critical turn in LL: New methodologies and new items in LL. Linguistic Landscape, 1(1-2): 6-18.

Bayley, A. 2016 Trans-forming higher education. Performance Research, 21(6): 44-49.

Bhabha, H. 1994 The location of culture. New York: Routledge.

Blackledge, A. 2019. Collaborative processes. In Moore, E., Bradley, J. and Simpson, J. (eds), Translanguaging as transformation: The collaborative construction of new linguistic realities. Bristol: Multilingual Matters.

Blackledge, A. \& Creese, A. (2017) Translanguaging and the body. International Journal of Multilingualism, 14 (3), pp. 250-268. DOI: https://doi.org/10.108 0/14790718.2017.1315809

Blommaert, J. 2013 Ethnography, superdiversity and linguistic landscapes: Chronicles of complexity. Bristol: Multilingual Matters.

Bradley, J. 2018 Translation and translanguaging in production and performance in community arts. $\mathrm{PhD}$ thesis, University of Leeds.

Bradley, J. and Atkinson, L. 2020 forthcoming. Translanguaging and bricolage: Meaning making and collaborative ethnography in community arts. In Moore, E., Bradley, J. and Simpson, J. (eds), Translanguaging as transformation: The collaborative construction of multilingual realities. Bristol: Multilingual Matters.

Bradley, J. and Moore, E. 2018 Resemiotisation and creative production: Extending the translanguaging lens. In Sherris, A. and Adami, E. (eds), Making signs. Translanguaging ethnographies: Exploring urban, rural and educational spaces. Bristol: Multilingual Matters. pp. 81-101.

Bradley, J., Moore, E., Simpson, J. and Atkinson, L. 2018 Translanguaging space and creative activity: Theorising collaborative arts-based learning. Journal of Language and Intercultural Communication, 18(1): 54-73.

Braidotti, R. 2013 The posthuman. Cambridge: Polity Press.

Brumfit, C.J. 1995 Teacher professionalism and research. In Cook, G. and Seidlhofer, B. (eds), Principle and practice in applied linguistics. Oxford: Oxford University Press. pp. 27-41. 
Butler-Kisber, L. 2010 Qualitative inquiry: Thematic, narrative and artsinformed perspectives. London: SAGE.

Crowley, T. 2017 Language, history, creativity. In Bradley, J. (Chair), Creative Inquiry in Applied Linguistics. Invited colloquium at British Association for Applied Linguistics. University of Leeds, UK, 31 August-2 September.

Facer, K. and Pahl, K. (eds) 2017 Valuing interdisciplinary collaborative research: Beyond impact. Bristol: Policy Press.

Frimberger, K. 2017 Performative approaches as critical pedagogy. In Crutchfield, J. and Schewe, M. (eds), Going performative in intercultural education. Bristol: Multilingual Matters.

Frimberger, K., White, R. and Ma, L. 2017 'If I didn't know you, what would you want me to see?': Poetic mappings in neo-materialist research with young asylum seekers and refugees. Applied Linguistics Review. DOI: https://doi. org/10.1515/applirev-2016-1061

Gardner-Chloros, P. 2014 Multilingualism and the arts: Introduction. International Journal of Bilingualism, 18(2): 95-98.

Harvey, L. 2020 Entangled trans-ing: Co-creating a performance of language and intercultural research. In Moore, E., Bradley, J. and Simpson, J. (eds), Translanguaging as transformation: The collaborative construction of multilingual realities. Bristol: Multilingual Matters.

Harvey, L. and Bradley, J. 2017 Embodied methods for communication research in higher education. In Leigh, J. (Chair), Embodied perspectives on research in higher education. Roundtable at Society for Research into Higher Education Annual Research Conference, Newport, UK, 6-8 December.

Harvey, L. and Vanden, K. 2017 Creative inquiry in adapting research for theatrical performance and public engagement. In Bradley, J. (Chair), Creative Inquiry in Applied Linguistics. Invited colloquium at British Association for Applied Linguistics, University of Leeds, UK, 31 August-2 September.

Harvey, L., McCormick, B. and Vanden, K. 2019. Becoming at the boundaries of language: : Dramatic enquiry for intercultural learning in UK higher education. Language and Intercultural Communication. DOI: https://doi. org/10.1080/14708477.2019.1586912

Harvey, L., McCormick, B., Vanden, K., Collins, M. and Suarez, P. 2019 Theatrical performance as a public pedagogy of solidarity for intercultural learning. Research for All, 3(1): 74-90.

Hazel, S. 2017 Mapping the Langscape - Developing multilingual norms in a transient project community. Journal of Linguistic Anthropology, 27(3): 308-325.

Hekman, S. 2010 The material of knowledge: Feminist disclosures. Bloomington, IN: Indiana University Press.

Huang, Z.M. 2017 Who am I? Researching the meanings of intercultural experience through creative-visual-arts. In Bradley, J. (Chair), Creative Inquiry in Applied Linguistics. Invited colloquium at British Association for Applied Linguistics, University of Leeds, UK, 31 August-2 September. 
Huang, Z.M. 2018 Mindfulness and intercultural personhood: Understanding students' intercultural experience at a culturally diverse UK university. Unpublished PhD dissertation, University of Manchester, UK.

Hult, F.M. 2010 The history and development of educational linguistics. In Spolsky, B. and Hult, F.M. (eds), The handbook of educational linguistics. West Sussex: Wiley-Blackwell. pp. 10-24.

Jaworski, A. 2014 Metrolingual art: Multilingualism and heteroglossia. International Journal of Bilingualism, 18(2): 134-158.

Jones, A. 2016 Introduction. Performance Research, 21(5): 1-11.

Jones, K. and Leavy, P. 2014 A conversation between Kip Jones and Patricia Leavy: Arts-based research, performative social science and working on the margins. The Qualitative Report, 19(19): 1-7.

Lather, P. and St Pierre, E. 2013 Post-qualitative research. International Journal of Qualitative Studies in Education, 26(6): 629-633.

Lawson, R. and Sayers, D. 2016 Sociolinguistic research: Application and impact. London: Routledge.

Latour, B. 1991 We have never been modern. Cambridge, MA: Harvard University Press.

Lee, T.K. 2015 Translanguaging and visuality: Translingual practices in literary art. Applied Linguistics Review, 6(4): 441-465.

MacLure, M. 2013 Researching without representation? Language and materiality in post-qualitative methodology. International Journal of Qualitative Studies in Education, 26 (6): 658-667.

McKay, S. and Bradley, J. 2016 How does arts practice engage with narratives of migration from refugees? Lessons from 'utopia. Journal of Arts and Communities, 8(1-2): 31-46.

Milde, A. 2017 Applied linguistics in drama practice. In Creative Inquiry in Applied Linguistics, Colloquium at British Association for Applied Linguistics, York St John University UK, 6-8 September.

Montuori, A. 2011 Creative inquiry: Confronting the challenges of scholarship in the $21^{\text {st }}$ century. Futures: The Journal of Policy, Planning and Future Studies, 44(1): 64-70.

Moore, E., Bradley, J. and Simpson, J. (eds) 2020 Translanguaging as transformation: The collaborative construction of multilingual realities. Bristol: Multilingual Matters.

Otsuji, E. and Pennycook, A. (2010). Metrolingualism: Fixity, fluidity and language in flux. International Journal of Multilingualism, 7(3): 240-254.

Pennycook, A. 2017 Translanguaging and semiotic assemblages. International Journal of Multilingualism, 14(3): 269-282.

Pennycook, A. 2018 Posthumanist applied linguistics. London and New York: Routledge.

Pennycook, A. and Otsuji, E. 2015 Metrolingualism: Language in the city. Abingdon/New York: Routledge. 
Phipps, A. 2013 Intercultural ethics: Questions of methods in language and intercultural communication. Language and Intercultural Communication, 13(1): 10-26.

Pöyhönen, S., Lehtonen, J., Haapakangas, E. and Raad Salih, H. 2017 Storytelling and story-listening as an artistic inquiry in a documentary theatre project. In Bradley, J. (Chair), Creative Inquiry in Applied Linguistics. Invited colloquium at British Association for Applied Linguistics, University of Leeds, UK, 31 August-2 September.

Prasad, G. 2018 'How does it look and feel to be plurilingual?': Analysing children's representations of plurilingualism through collage. International Journal of Bilingual Education and Bilingualism. DOI: https://doi.org/10.1 080/13670050.2017.1420033

Rowe, N. and Reason, M. (eds) 2017 Applied practice: Evidence and impact in theatre, music and art. London: Bloomsbury.

Sagan, O. 2017 Thou art, I am: Discovery and recovery in the art-making process. In Rowe, N. and Reason, M. (eds), Applied practice: Evidence and impact in theatre, music and art. London: Bloomsbury. pp. 172-189.

Simpson, J. 2018 Toinen Koti - Other Home. [Online]. TLANG Blog. Available at https://tlangblog.wordpress.com/2018/02/04/toinen-koti-other-home/ [Accessed 29 January 2019].

Thurlow, C. 2016 Queering critical discourse studies or/and performing 'postclass' ideologies. Critical Discourse Studies, 13, 485-514.

Toohey, K. 2018 The onto-epistemologies of new materialism: Implications for applied linguistics pedagogies and research. Applied Linguistics, DOI: https://doi.org/10.1093/applin/amy046

Turvey, L. and Walton, A. 2017 Art, audience, artist: Exploring the practice of learning with art. In Turvey, L., Walton, A. and Daly, E. (eds), In Site of Conversation: On Learning with Art, Audiences and Artists. London: Tate. pp. 11-22.

Weinstein, J. and Colebrook, C. 2017 Introduction: Critical life studies and the problems of inhuman rites and posthumous life. In Weinstein, J. and Colebrook, C. (eds), Posthumous Life: Theorizing beyond the Posthuman. New York: Columbia University Press. pp. 1-17.

Zezulka, K. 2019 Using linguistic ethnography to examine the language of theatre production. In Wright, C., Harvey, L. and Simpson, J. (eds), Voices and practices in applied linguistics - diversifying a discipline. White Rose University Press.

Zhu H., Li W. and Lyons, A. 2017 Polish shop(ping) as translanguaging space. Social Semiotics, 27(4): 411-433. DOI: https://doi.org/10.1080/10350330.2 017.1334390 